\title{
EDITORIAL
}

DOI: http://dx.doi.org/10.1590/S0034-759020170501

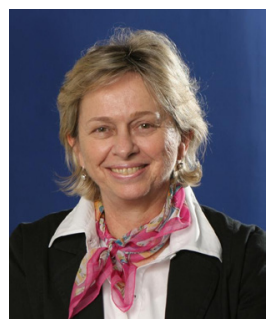

MARIA JOSÉ TONELLI Editor-in-Chief*

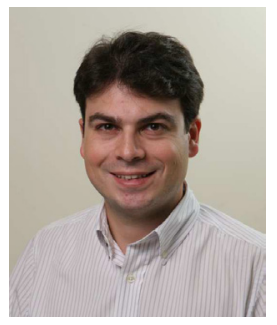

FELIPE ZAMBALDI

Assistant Editor*

\section{RESEARCH THEORY, PRACTICE, AND PARADIGMS}

In 1990, Gioia and Pitre published an enlightening article about theory construction in the Academy of Management Review journal. Based on the Burrell and Morgan (1979) classic model, the authors reported that despite the majority of studies in our area being supported by the functionalist approach, our area is multi paradigmatic. They also presented the possibility of constructing theory and contributing knowledge from interpretative approaches, such as radical humanism and radical structuralism. The authors declared that these approaches present permeable borders, different from the boundaries that seek to confine them. Models are symbolic representations of reality, which cannot be confined in a singular form.

Since 1979, epistemological perspectives creatively multiplied, although bases for their classification can be found in a classic book by Burrell and Morgan. However, almost 30 years after Gioia's publication, researchers still insist on considering only the functionalist approach as credible. This represents a loss for the Brazilian Administration research context, which is theoretically and practically unable to benefit from advances developed in multiple approaches.

In the academy, we are prisoners of binary thoughts that currently define politics and begin to determine how to engage in science using mode 1 or mode 2, either applying theory or practice. The famous statement, "nothing more practical than a good theory" by K. Lewin is still applicable but has not yet reached many researchers in our area. Lewin significantly influenced the development of research-action, organizational change, and development practices. Science also encompasses long-term knowledge with results that may not be used for immediate practical purposes, but this does not mean we should stop conducting research. This matter also attributes different weights and measures to these modes of knowledge production. How can we make Administration research more democratic, which is an essential condition for developing any science? How do we incorporate accumulated knowledge in company practices? Gioia and Pitre (1990) also reported that people do not like to change their manner of thinking and new approaches are not always welcome. We hope that RAE's articles will help to contribute to the construction of Administration knowledge.

$R A E$ restates its multi paradigmatic scope in this issue. The article entitled, “El rol del consejo de Administración en la ética empresarial en países de Latinoamérica”, which quantitatively analyzed 100 companies in the region, addresses a relevant theoretical and practical matter in the current context and points out the positive effects of female participation and an independent council in this collegiate. In “Organizing: Compreendendo interações e práticas do Grupo Galpão”, based on the theoretical debate promoted by Weick and Czarniawska, the authors investigate a theater group, question the rarified thinking of organizations, and stimulate researchers to seek understanding of the processes in small and medium companies. In "Diagnóstico e análise das competências dos conselheiros de Administração", which is also about councils, the necessary abilities of council members for closed capital companies are analyzed and it is pointed out that behavioral competencies are more relevant 
than technical competencies, and "power attachment," among other factors impairs the counselor's performance. Essential at the moment is the article, "Acordo setorial de embalagem: Avaliação à luz da responsabilidade estendida do produtor”, which debates the impact of policies promised by sectorial agreements in the Brazilian recycling chain. "The taste transformation ritual in specialty coffee market" illustrates through ethnographic research how consumers transformed their taste for coffee, with theoretical explanations based on consumption theory. Finally, the article "Prospect theory: A parametric analysis of functional forms in Brazil" analyzes the risk preferences in Brazil, with practical results on resource usage.

As observed, this edition presents a diversity of knowledge areas in Administration-Strategy, Organizations, Logistics and Sustainability, Marketing and Consumption, and Finance and Behavior-with articles about distinct epistemological perspectives by researchers from various Brazilian and international institutions.

In the last edition, we inaugurated the Perspectives session and addressed the subject of internationalization of Brazilian journals. In this $R A E$ issue, editors of outstanding journals about Administration were invited to write about the periodic role in the national scenario. We have assays by Ariádne Scalfoni Rigo, editor of Organizações \& Sociedade (Organizations \& Society [O\&S]), about "Comunidade acadêmica, produtivismo e avaliação por pares” and Maria Sylvia M. Saes, editorin-chief of the Revista de Administração (Management Journal [RAUSP]), Adriana Marotti de Mello, and Luisa Veras de Sandes-Guimarães, "Revistas brasileiras em Administração: Relevância para quem?”. These texts complement one another, since they address various aspects of journal production in the current local scenario. These are questions that all of us from the academic community must discuss, debate, and create solutions.

Completing this edition, further book reviews - "Repensar e reaprender na era pós-digital” by Lucas Rodrigo Santos de Almeida and "Measurement error and research design: Preenchendo o gap entre teoria e método" by Vitor Koki da Costa Nogami, the book recommendations section about Qualitative Interviews by Benjamin Rosenthal, and Digital anthropology by Rita de Cassia Alves Oliveira, are included.

Enjoy a good read!

\section{Maria José Tonelli and Felipe Zambaldi}

* Professors at Fundação Getulio Vargas, Escola de Administração de Empresas de São Paulo - São Paulo - SP, Brazil.

\section{REFERENCES}

Burrell, G., \& Morgan, G. (1979). Sociological paradigms and organisational analysis: Elements of the sociology of corporate life. London, UK: Heinemann Educational Books.

Gioia, D. A., \& Pitre, E. (1990). Multiparadigm perspectives on theory building Academy of Management. The Academy of Management Review, 15(4), 584-602. doi:10.5465/ AMR.1990.4310758 